\title{
Modern museums in the palaces of the western Grassfields, Cameroon
}

\author{
Mathias Alubafi Fubah \\ Human Sciences Research Council (HSRC), South Africa
}

\begin{abstract}
Introduction: This paper suggests that the recent interest in modern museums in the palaces of the Grassfields is obscurely associated with the need to transform the palaces and, more importantly to address the multiple problems plaguing the royal treasury or traditional palace museums. The paper argues that unlike the royal treasury, the modern museum is significant, partly because it constitutes a democratic space, and partly because it articulates and can be associated with the irony of change and continuity.
\end{abstract}

Method: The findings are based on qualitative data collected from documents and from ethnographic studies on the emergence of modern museums across the region.

Results: The paper has contributed to the scholarship on Cameroon, and, in particular, extended Michael Rowlands' (2008) seminal work on curating postcolonial pasts in the Grassfields by unveiling the modern museum as a democratic lens through which to view the undemocratic royal treasury.

Policy implications: The study suggests among others, the need for the Grassfields population to embrace the modern museum - and to see it as a continuation of the royal treasury. The practical implication is to tailor the modern museum to the socio-cultural needs of the target population-particularly women and youths since they are generally excluded from the activities of the royal treasury. Key words: royal treasury, museum, Cameroon, Grassfields, Bambui, youths

\section{Introduction}

In 20I0, I received an email from the chairman of the Bambui Traditional Council (BTC) with a project proposal titled Bambui Museum and Ecotourism Project (BMEP). The proposal was a follow-up to a meeting held in the Bambui palace in December 2005. The aim of that meeting was to revisit some of the projects that had been earmarked for the palace since 2000 , and to deliberate on what could be done in order to raise the funds required to kick-start the projects. Most notable among these projects was the BMEP, an initiative that came about as a result of the call for applications for the creation of modern museums in some palaces of the Grassfields by the Centro Orientamento Educativo (COE), an Italian NGO in $200 \mathrm{I}^{\mathrm{I}}$ Although Bambui was not selected by the COE, the idea 
of a modern museum in the palace did not diminish - it continued to gain support from across the village, and specifically from the Bambui Cultural and Development Association (BACUDA) and the BTC. ${ }^{2}$

As someone from Bambui with a background in museum studies, I was assigned from the outset to work with the BTC chairman on the BMEP proposal. His email was, therefore, intended for me to make the necessary corrections and to return it to be deliberated on during the Annual General Meeting (AGM). "Remember the meeting we held in the palace last year (2009) and our last telephone conversation" he stressed in his email. "Now is the time to convince BACUDA and the BTC that we need to kick-start the BMEP in the New Year (20II) - everyone in the village is willing and ready to contribute, but I need your support with refining the proposal again," he concluded. ${ }^{3}$

Having participated at the inauguration of the Mankon and Babungo museums in 2005/2006, I realised how disappointed, yet, determined, some of the kingdoms were, especially considering that their applications returned void (figs. I and 2). The inauguration ceremonies of the two museums were filled with fanfare - in fact, they were similar to what Michael Jindra calls "social jamboree" (2005: 360-I) in the Cameroon Grassfields. ${ }^{4}$ They attracted sons and daughters of Mankon and Babungo from across Cameroon. Dignitaries, specifically government representatives, traditional rulers, academics, and special guests from both the public and private sector flocked to the Mankon and Babungo palaces to witness the event and to register their full support for the initiative. It was an occasion for the fon of Mankon, Angwafor III, to shower praises on the president of Cameroon, Paul Biya, and his ruling party, the Cameroon People's Democratic Movement (CPDM) for the initiative. It also served to remind those in attendance about what the government can do for them. ${ }^{5}$ As with other social jamborees across the region, the

www.archives.icom.museum/definition, 23/10/2013). Modern museum describes the change from the traditional palace museum or royal treasury to this new institution.

A distinction between the two association is necessary for a better understanding of the place of youths and elites in the Grassfields. BTC is essentially for elites and tiltle holders. Elites and title holders as used here are people with elaborate hierarchies, mostly headed by kings, who are known throughout the region as fons. These hierarchies are generally centralized in the palace, which is also the capital of the kingdom or village. BACUDA on the other hand is made up of youths or young men between the ages of $\mathrm{I} 8$ and 45 years, and who normally do not have traditional titles, except in cases where they have been awarded such titles either as successors to their mother or father or in recognition of their contribution to development in the society. Most youths and youth associations are associated with modernist aesthetic while elites and titleholders are associated with local or traditional aesthetics (cf. Argenti I998, 200I; Fubah 2014).

3 It should be noted that the BTC chairman's statement was based on the outcome of successive meetings with members of the BTC and the local community about the need for a museum in the palace to replace the royal treasury.

$4 \quad$ Michael Jindra was referring to a man from the Grassfields who likened traditional death celebrations or second funerals, (the celebration that used to be performed approximately a year or more after the first funeral or burial across the western Grassfields) to a social jamboree. Nowadays, it is performed approximately a day or two after the first funeral in Bambui.

5 Although the inauguration of the Mankon palace museum was meant to be something like a cultural jamboree, it soon became political, specifically because the fon of Mankon, fon Angwafor III is the vice president of the ruling party, the Cameroon Democratic People's Movement (CPDM). Across Cameroon, it is not uncommon for socio-cultural gatherings to be turned into political campaign meetings and rallies. 
ceremonies were an occasion for "people to meet potential mates, discuss village affairs, get news, exchange gossip, renew friendships and meet distant relatives" (Jindra 2005: ${ }_{36 \mathrm{I}}$ ), as well as to plan for the day that a similar occasion will come to fruition in their own kingdom or palace. The BTC chairman's email to me was a step in this direction.

Since the launching of the COE initiative in 200I, numerous kingdoms as well as contemporary and youth associations across the western Grassfields have rekindled and are rekindling their efforts towards constructing their own palace museums. The period in question, can, therefore, be associated with the dawn of the modern museum in the palaces of the western Grassfields. Up until then, only royal treasuries or traditional palace museums existed in palaces across the region, hence I refer to the change from the traditional palace museum to the new institution, and the implications that this has for traditional curatorial practices. From Tubah Sub-division to Ngokitunja, Bui and Donga Matung Divisions, there was, and still is talk about the need for museums in the palaces, prompting one to ask whether the inspiration for this is solely from the COE initiative or something else. Although this has been going on for over a decade, it has not received the attention it deserves from academics.

But why has the notion of a modern palace museum become so popular across Bambui and the western Grassfields? Why have most of the contemporary and youth associations such as the BACUDA and Bambui Youth Beginners Association (BYBA) developed an interest in a modern museum in the palace? What has gone wrong with the traditional palace museum or royal treasury? If the newly created Mankon palace museum is a white

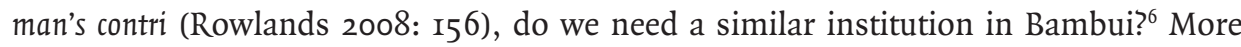
importantly, of what significance is the modern museum in Bambui palace? This paper attempts to grasps some of these issues by way of studying the motivations for the recent upsurge in interest in modern palace museums across the western Grassfields. Closer inspection reveals a new and foreign aesthetic has evolved in the art and museum sector in the Grassfields which deserves more attention from anthropologists and art historians than it has hitherto received.

This paper suggest that the recent interest in modern museums in the palaces of the western Grassfields is obscurely associated with the need to re-traditionalize the palaces and, more particularly, to address the multiple problems plaguing the traditional palace museums. ${ }^{7}$ The paper argues that the modern museum unlike the royal treasury is significant, partly because it constitutes a democratic space within the palace, and partly because it can be associated with, and articulates, the irony of change and continuity. This perspective draws on and contributes to the scholarship on Cameroon and, in particular, Michael Rowlands's (2008: 153) seminal work on curating postcolonial pasts in the Cameroon Grassfields in which he argues that "fons in the Grassfields, today as in the past, have a duty to appropriate and bring inside the kingdom all the resources that

6 Contri is the pidgin term for country and white man contri is the country of the white man.

7 By re-traditionalize, I should be understood as referring to the initiative and efforts by contemporary and youth associations aimed at promoting and preserving not just what is still left of their past but also by collecting and bringing what they see as tradition nowadays to the palace for preservation. 
circulate outside of it." This paper goes a little further, recognising not only the role of the fon, but also that of contemporary and developmental associations (such as BYBA and BACUDA), as well as the community in ensuring that the palace remains the centre of activities within the kingdom. I intend to demonstrate that the modern museum in the palace is significant because it represents the irony of change and continuity - thereby enforcing the notion of the palace as a mediator between tradition and modernity. ${ }^{8}$

These contemplations allow me to adopt the following approach in the study of the motivations for modern museums in Grassfields palaces. First, I identify and examine the significance of the royal treasury in the Grassfields, (drawing particularly on my fieldwork experience) and highlight its weaknesses. Second, I examine the modern museum as a tool for re-traditionalizing the palace. Third, I present the modern museum as a means of affirming the politics of lobbying and bringing inside the palace all resources circulating outside. Fourth, I discuss the modern museum as an instrument in the efforts of Bambui youths to have a say in the royal treasury and resources circulating outside the kingdom as elders and titled men have always had. These analyses, then, provide an opportunity to understand some of the reasons behind the growing interest in modern palace museums across Bambui and the Grassfields.

The findings are based on qualitative data collected from various documents and ethnographic studies on the emergence of modern museums across the region. Between 2005 and 2006, and during intermittent visits in 2009, 2010, 2012 and 2013, a total of 30 interviews were conducted with museum officials, relevant government departments, members of BYBA, visitors to the museums, and selected members of the public. Interviews were conducted in Bambui and in the newly constructed museums of Mankon and Babungo as well as in offices and homes of the selected interviewees. The findings are the basis of this paper.

\section{From royal treasury to Modern Museum}

The Bambui Kingdom in the western Grassfields is reputed for its artistic and cultural heritage resources, and especially for its royal treasury that promotes and preserves these resources. The partiality of the kingdom to lobby for and appropriate not only artistic and cultural heritage resources, but also all valuable resources circulating outside its borders and Cameroon has led over the years to an obsession with prestigious items and foreign aesthetics. For example, a large number of the artistic as well as cultural heritage and related resources in the royal treasury across the kingdom are both from within and from outside the kingdom and country. Because of the sacred nature of most of the objects in the royal treasury in Bambui, and the related paraphernalia of the sacred, access is restricted to initiated members or those who have been empowered to view them, noninitiates (most of them youths, untitled men and social juniors) have been compelled to look elsewhere to gain access to the treasures of the kingdom. Over the past ten years or so, interest in modern museums in the palaces of the western Grassfields has grown to

8 By tradition and modernity here, I should be understood as referring to the aspects associated with traditional palace museum or royal treasury and those associated with the modern museum. 
the extent that people no longer talk about the royal treasury. It is for these reasons that in the Grassfields context dominated by the politics of obsession with prestigious items and foreign resources, interest in modern museums has become the preoccupation of the entire region to the extent that it is now seen as a threat to the very existence of the royal treasury.

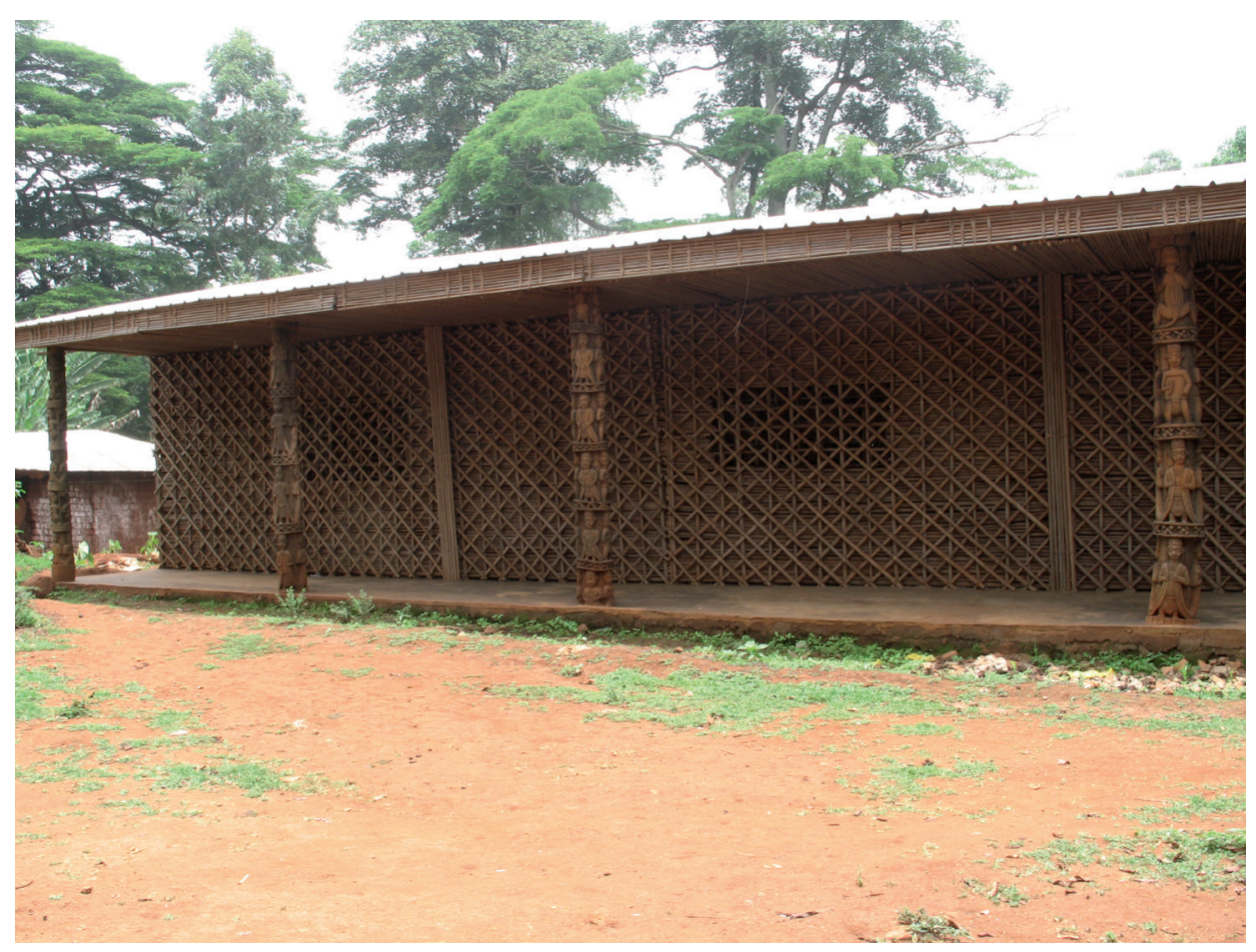

Figure 1: External view of the Babungo museum. Babungo, Cameroon, April 2005

However, interest in the modern museum is not unique to the Bambui Kingdom. Recent studies have demonstrated that over two hundred applications were received when the COE launched the initiative to construct museums in some palaces in the region (Notue 2000; Notue and Bianca 2005, 2006; Rowlands 2008; Fubah 2013). This suggests that most kingdoms, including Bambui, saw the initiative as a response to the declining state of the royal treasury, and in particular an opportunity to address the problem of secrecy surrounding the use of the royal treasury. It is for this reason that most Grassfields palaces, including, Bambui, Kedjom Keku and Kedjom Ketingo are currently lobbying for funds to construct their own modern museums. 


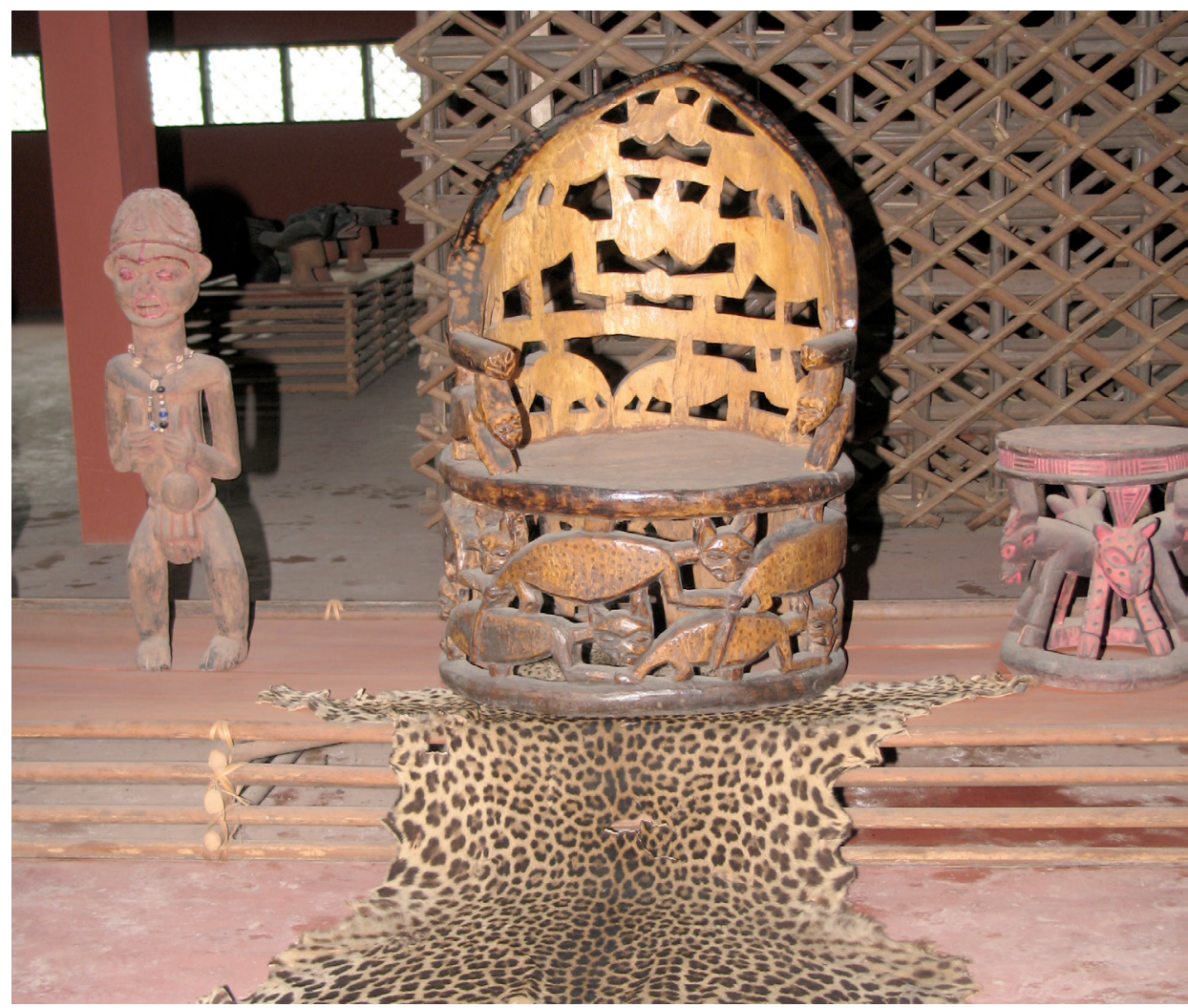

Figure 2: Internal view of a cross-section of the Mankon museum, Cameroon, April 2005

Much has been written about the royal treasury in the Grassfields, but little about the crisis of custodianship facing the institution, and the recent interest in modern museums in the palaces of the western Grassfields. Characteristic of this interest is the tendency of most Bambui youths to associate the modern museum with education, and to exalt it as a means to achieve their dreams of modernity, and at the same time to denigrate it as a threat to sacred objects and something that belongs to the West. In fact, if Bambui, and by extension, kingdoms across the Grassfields show interest in modern museums, it is because they are descendants of a culture that believes in collecting, promoting and preserving the artefacts of the palace and kingdom.

Bambui people also show an interest in the modern museum because it is one notable means of bridging the gap between titled men and elders - those who control access to the royal treasury - and untitled men, women and youths who are denied access to such places. As a matter of fact, untitled men and commoners are associated with secular art-which in most cases is not part of the royal treasury. Thus, having a modern museum in the palace will empower everyone because objects from the royal treasury, including some sacred pieces will be cleaned up and displayed in the museum for public entertain- 
ment. ${ }^{9}$ With the objects from the previously secluded royal treasury displayed in an open museum for the general public, the modern museum can rightly be presented as a means through which Bambui, and by extension, Grassfields untitled men and commoners can achieve their "statutory quest" (Seraphin 2000: II7). In other words, having access to treasures from the royal treasury by viewing them in the modern museum as opposed to the previous situation in which they were denied access. This is also one of the reasons why Bambui youths and untitled men consider the modern museum important, because it enhances their social status both in Bambui and beyond (cf. Warnier I993; Rowlands I996).

However, while most members of contemporary and youth associations across Bambui see the modern museum in the same manner as the royal treasury, some are, somewhat skeptical, on the grounds that the modern museum does not reflect a true Bambui identity, especially in terms of the secret nature of the objects stored in the royal treasury. In a region where the royal treasury is considered the "power" base of the kingdom, many Bambui youths and untitled men feel that exposing the treasures of the kingdom to the general public will "disconnect" rather than reconnect the indigenes and their ancestors - represented by the objects. In fact most of my informants argued that having modern museums in Grassfields palaces as a replacement for the royal treasury, might be a curse rather than the much expected blessing of villages promoting and preserving the objects left behind by ancestors in the royal treasury. Similarly, some kingdoms, such as Kom, for example, opposed the COE initiative to construct a modern museum in Kom palace because they were afraid of exposing afoa-kom or "things of the palace" stored in the royal treasury to the public through the modern museum. Yet, in spite of these reservations, most of the modern museum skeptics are still concerned about the implications of not having one in their palace in modern day society.

\section{Modern museums as a means of re-traditionalising the palace}

To better understand how the modern museum can also function as a royal treasury in today's society, it is necessary to briefly address the theoretical question of the notion of tradition as implying stability and absence of change, especially considering that such views have been challenged by several scholars in recent decades (Fabian I983; Hobsbawn and Ranger I983; Clifford I988; Ranger and Vaughan I993). The above scholars all emphasize the highly conceptual and illusionary character of tradition, and in the case of this paper, the royal treasury. Moreover, anthropologists have realized that, whatever a society does is part of the people's attempt to understand their situation and grapple with changing conditions. Hence, the interest in modern museums in the palaces of the Grassfields, is not only because contemporary and youth association members are obsessed with prestige items or want to lobby and bring inside the kingdom all resources circulating outside of it, like the titled men and elders. The interest is also a way in which youths produce meaning enabling them to examine and shape their life condition. 
For Bambui youths, as well as untitled men and women, their engagement with the changing conditions of today's society is manifested in their ability to lobby and have modern museums in the palace(s) as a means to construct an imagined royal treasury and, in particular, to redress the crisis facing the royal treasury. Additionally, it is meant to reconnect them to the local community in order to be seen as men following in the footsteps of elders and titled men in the community - and therefore, capable of promoting and preserving their artistic and cultural heritage resources. In this case, modernity or the modern museum presents itself simply as continuity with the past and emphasizes the historical depth of the system of traditional museums or royal treasury in the Cameroon Grassfields (cf. Forni 200I; Nettleton et al. 2002; Geschiere et al. 2008). Hence, while the terms "tradition" and "modernity" may be used to explain different kinds of "situations, and acts, these categories are not perceived as intrinsically oppositional or strictly defined" (Forni 200I: 27). However, as used here, the term modern highlights the change from the royal treasury to the modern museum.

Apparently, there is no region in Cameroon where having a modern museum in the palace is considered a means of re-traditionalizing the palace as is the case across the Grassfields, and Bambui, in particular; no place where contemporary and youth associations have shown interest in modern museums as a symbol of prestige and power, or an instrument in their effort to have a say in the management of the royal treasury; no place where the modern museum is associated with the task to appropriate and bring inside the kingdom all the resources circulating outside of it - as is the case in Bambui and the Grassfields (cf. Fubah 2013). No Grassfields scholar has undertaken an in-depth study of the rationale behind the recent upsurge of interest in modern museums in the palaces of the western Grassfields. The paucity of research on the recent interest in modern museums in the region suggests that many realities that ought to be known remain largely unexplored.

Nkwi Paul's (I996) work on a conservation dilemma in the Cameroon Grassfields, has in many ways drawn our attention to the rise and fall of the royal treasury. Highlighting the crisis facing the royal treasury and the need for modern museums in the palaces of the Cameroon Grassfields, Nkwi notes that the royal treasury that was at its peak in the I940 and I950s is now at its lowest ebb and needs urgent attention. He maintains that, in the past, palace retainers or traditional curators were "recruited throughout the kingdom to cater for the royal treasury: former retainers were required to send sons to the palace to serve while some were forcefully recruited from among the brightest young men of the kingdom." Up to the I940s and I950s, Nkwi notes, the regulatory society, rather than modern education, constituted the fastest means of gaining social recognition. As a result, the royal treasury had sufficient curators looking after the masks of the different lodges (1996: 103-4). By the ig6os, however, modern education became popular, forcing parents to send their children to school rather than allowing them to work in the palace. The outcome of this was that the royal treasury ran out of staff or curators and thereby exposed the masks of the palace lodges to an increased threat of theft (Nkwi I996: I04). 
The above observation echoes what other Grassfields scholars have written, and reflected extensively on (Assombang I990; Notue 2000; Notue and Bianca 2005, 2006; Fubah 2013). Moreover, it highlights the state of affairs in the Bambui royal treasury pointing to the need for a modern museum. It also reveals the undemocratic side of the system of recruiting palace retainers, pointing to some of the reasons why the system later became unpopular and unsustainable, especially following the introduction of formal education from the late colonial era until present day. It also demonstrates that having a modern museum in the palace is one notable means of ensuring that the palace is re-traditionalised, since most educated young men have abandoned the royal treasury in favour of education which ties into the modern museum concept. As a matter of fact, it is through the modern museum that educated Bambui youths and contemporary association members are considered part of the palace and kingdom since for many people from Bambui and the Grassfields, one is a true member of his community only if he associates with the artistic and cultural heritage of his village in the same manner as elders and titled men do with the royal treasury. This means that ownership of a modern museum allows the Bambui youths the opportunity to promote and preserve the artistic and cultural heritage of the kingdom, thereby helping to address the crisis facing the royal treasury. In other words, Bambui youths and contemporary association members see the modern museum as part of the modern society in which they live rather than the royal treasury which no longer produces high social status.

In Bambui in particular and the Grassfields as a whole, people generally scorn contemporary and youth association members who do not concern themselves with the development of their palace, tending to address them as commoners or even "nobody", in some cases..$^{\text {IO }}$ For instance, a Bambui elder confronted me in 2004 when I was conducting fieldwork for my PhD and questioned me angrily about when I will start contributing to the development of the palace. As one of the educated titled men in Bambui who also knew I was working on art and museums, I assume he wanted to know when I will be able to help improve the deplorable state of the royal treasury. His question did not fall on deaf ears - it provoked me to write a book on The Art of the Bambui Kingdom (2014) that will serve as a guide in Bambui's endeavor to have its own palace museum. In a similar situation, during the 20I0 AGM in the palace, the president of BACUDA challenged his members to prove their worth by removing the sore from the eyes of the village - by which he meant giving the palace a new face-lift rather than just intimidating people with titles like Doctor ' $\mathrm{A}$ ' or ' $\mathrm{B}$ ' or lawyer ' $\mathrm{C}$ ' or 'D'. He reminded all those carrying traditional, academic and other titles, that such titles also come with responsibilities - and in the case of Bambui, nothing could be more important than improving the deplorable state of the palace, and the royal treasury which in the eyes of everyone is the gateway into Bambui. Given the poor state of the royal treasury and the popularity and interest in having modern muse-

Io By commoners here, I should be understood as referring to ordinary members of the Bambui public who are not affiliated to the royal family and who also do not have titles at the lineage level. Commoners are generally segregated against and marginalized in traditional communities in the Cameroon Grassfields as opposed to titleholders and notables who are highly respected (cf. Notue 2000; Notue and Triaca 2005, 2006 for more on notables and commoners). 
ums in palaces across the Grassfields, one can rightly ascertain that the BACUDA president was also reiterating the need for a modern museum in the Bambui palace.

\section{Modern museums and the accumulation of resources}

Over the last couple of years, most Bambui young men and women, especially those in contemporary and youth associations, have come to be convinced that the one notable means of attaining their goals and social status is to have a modern palace museum that reflects the demands and needs of present day society. Accordingly, many have come to associate ownership of the modern museum with the affirmation of ethnic and social

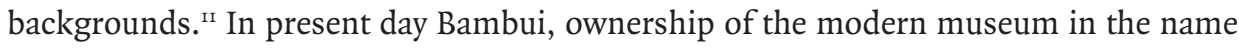
of Bambui and ethnic pride in resources circulating outside its border is more important than ownership for the sake of status and social recognition, because many Bambui contemporary and youth association members feel the modern museum now serves less as a signifier of social status than as a marker of social identification. ${ }^{12}$ In fact, having a modern museum in Bambui palace is concrete proof that contemporary and youth association members form an important part of the Bambui traditional and contemporary elite class. It is also a confirmation that, despite the restrictions associated with the royal treasury, and its eventual decline, youths can still make the treasures of the kingdom available and accessible to all through the modern museum. For most Bambui youths, a modern museum can also serve as a store room for the "things of their time" in the palace, which marks their place in the Bambui traditional hierarchy, since it is through accumulating, promoting and preserving the treasures of the kingdom that youths can obliterate the social stratification between traditional elites and themselves. ${ }^{13}$ By so doing, having a modern museum as a symbol of ethnic affiliation neutralizes the distinction between traditional elites and youths (cf. Malaquais 2002).

The experiences of Bambui contemporary and youth association members support this marked change through the growing interest in the modern museum. Until the early and mid-200os when most Bambui contemporary and youth association members started to show interest in the modern museum, artistic and cultural heritage resources (including those from outside) of the kingdom were stored in the royal treasury and they served as an instrument in the traditional elites search for status and social recognition, and in their struggle for control of the local population and resources (Geary I98I; Argenti I998; Homberger 2008). Having access to resources both from within and from youths to own a modern museum in line with the contemporary world in which they live.

12

I3

The team ownership as used here refers to the act or right to own something. It denotes the right by Bambui By resources, I should be understood as referring to the stock of materials, be they cultural or otherwise that can be drawn on by a person or youths or an organization in order to function effectively.

In Bambui and kingdoms across the Grassfields, the power and authority of traditional elites rest almost entirely on their control over the things of the palace, most of which are preserved in the royal treasury or traditional palace museums. Youths and contemporary association members, especially those who are not initiated into some of the secret societies that make use of the objects are not given access to the royal treasury. Accordingly, most youths and contemporary association members see the idea of lobbying and having a modern museum in the palace as a means of narrowing the barrier created between them and traditional elites through restriction imposed on the royal treasury. 
outside the kingdom also played a decisive role in the desire of these elites to gain access to the notability necessary to re-enforce their power. This was the case with successive Bambui leaders and elites whose hospitality and openness to the first missionaries, the Basel Mission (now Presbyterian Church in Cameroon) contributed in bringing Christianity to Bambui in the early I930s. In I942, the then fon or king of Bambui, Acheyifor II, again, lobbied and had the first primary schools from the Catholic Mission Authority (CMA) and the Native Authority (NA). The Catholic Mission School was named Saint Peter's School, Bambui, while the Native Authority School was called N. A School, Bambui. The two schools attracted pupils from neighbouring kingdoms such as Kedjom Keku, Kedjom Ketingo, Nkwen, Bambili and Bafut, eventually making Bambui, a "catchment village" for education (Bonu 2012: 83).

His successor, fon Amungwafor II (I947-I995) continued his legacy, campaigning and having the first college, Saint Peter's Teacher's Training College (TTC) Bambui, in

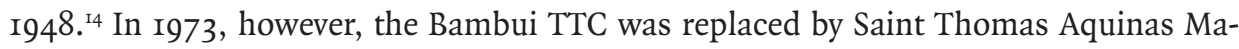
jor Seminary (STAMS), Bambui. Over the years, Amungwafor II continued to lobby and bring more resources circulating outside the kingdom into his kingdom until I 975 when a group of Bambui elites living and working in cities across Cameroon founded BACUDA and the BTC to assist the fon in promoting culture and development across the kingdom. By 1995 when Amungwafor II also went missing or died, Bambui had made significant progress towards accumulating both local and foreign resources. ${ }^{15}$ Amungwafor II was succeeded by his sons, Angafor Mombo-o III, who since taking over has also been able to campaign and bring inside the kingdom two secondary schools - Government Secondary School (GSS) Macha, and Government Technical College (GTC), Bambui. Following the recent creation of the University of Bamenda in 2010, Bambui has also allocated a reasonable portion of land for some of the departments. Hence, the interest in a modern museum in the Bambui palace is nothing new - it is a mere continuation of an age old practice. But the responsibility for achieving this rests more in the hands of contemporary and youth association members than with elders and titled men.

\section{Modern museums and Bambui Youths}

A number of recent studies on the Cameroon Grassfields have reiterated the fact that accumulation of local and foreign resources, today, as in the past, is essentially a political phenomenon (Geary I98I; Argenti 200I; Ndjio 2009; Malaquais I999, 2002; Rowlands 2008). This is true, especially for the modern museum, because, since the formation of powerful Grassfields kingdoms in the late I7th and I8th centuries, similar institutions have played a crucial role in the constitution of an extraordinary power by Grassfields fons and in their achievement of their hegemonic enterprise, as many studies about the region have shown (Geary I98I; Argenti 200I; Ndjio 2009; Rowlands I996, 2008; Homb-

I4 The Saint Peter's Teacher's Training College (TTC) was first opened in Njinikom in I947, but later transferred to Bambui because of bad roads to Kom in comparison to Bambui.

I5 Across the Grassfields, and Bambui in particular, traditional rulers or fon or king never died. When one dies, he is considered to have disappeared and will re-appear. As a result, people normally say the king has gone missing. 
erger 2008). Right from the beginning, Grassfields fons have made traditional museums a means of exaggerating their importance and authority before their subjects, and especially a form of administration that favours titled men and elders at the expense of commoners as well as untitled men and women. The royal treasury served as a royal institution and ownership was restricted to the palace, and accessibility limited to male elites, and in some cases, only initiated members of the secret societies or those who have been empowered to be members. As a matter of fact, the royal treasury served as a tool in the local elites search for status and social recognition, and in their struggle for control of the local population. By tradition, the royal treasury was, and still, is one of the most important, and yet, undemocratic institutions in palaces across the Grassfields and Bambui, in particular.

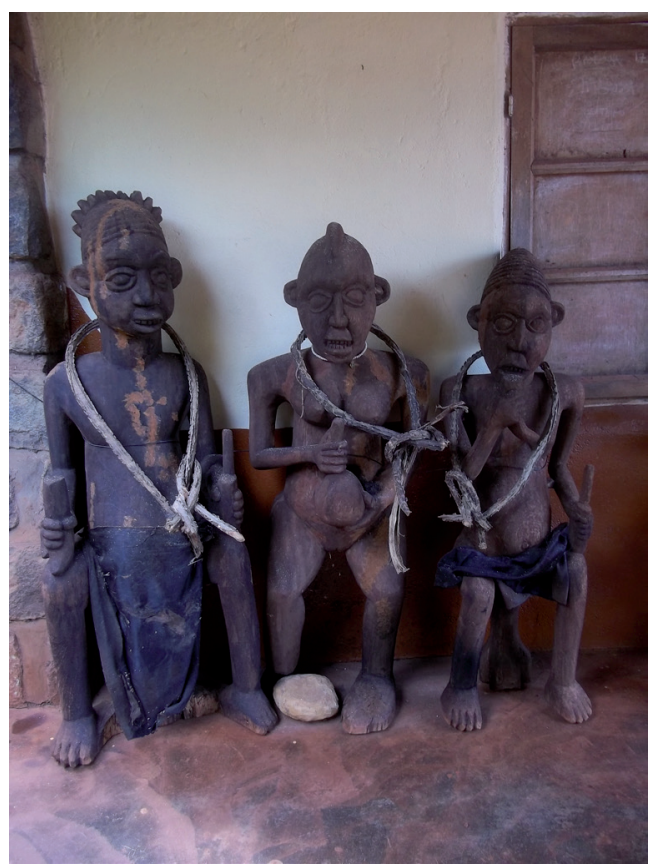

Figure 3: Injiumnto-oh or things of the palace. Royal status stored in the royal treasury, Bambui. They are brought out and exhibited once a year, during the annual dance for the general public to view. Bambui, May 2012

In contrast to the privileges associated with male elites and the royal treasury, commoners, including untitled men, youths and women were, and still are, restricted from accessing the objects in the royal treasury. Access to the treasures in the royal treasury, is limited to the annual dance when certain pieces of objects are brought out and displayed (fig. 3). As a rule, women, especially those considered unclean are not allowed to view certain mask groups and objects during the annual dance. As noted by Hans Knöpfli, a "woman is regarded as unclean for seven days when she has her monthly period, while 
men are considered unclean for three days after sexual intercourse as they might unknowingly have had contact with an unclean woman" (I997: I7).

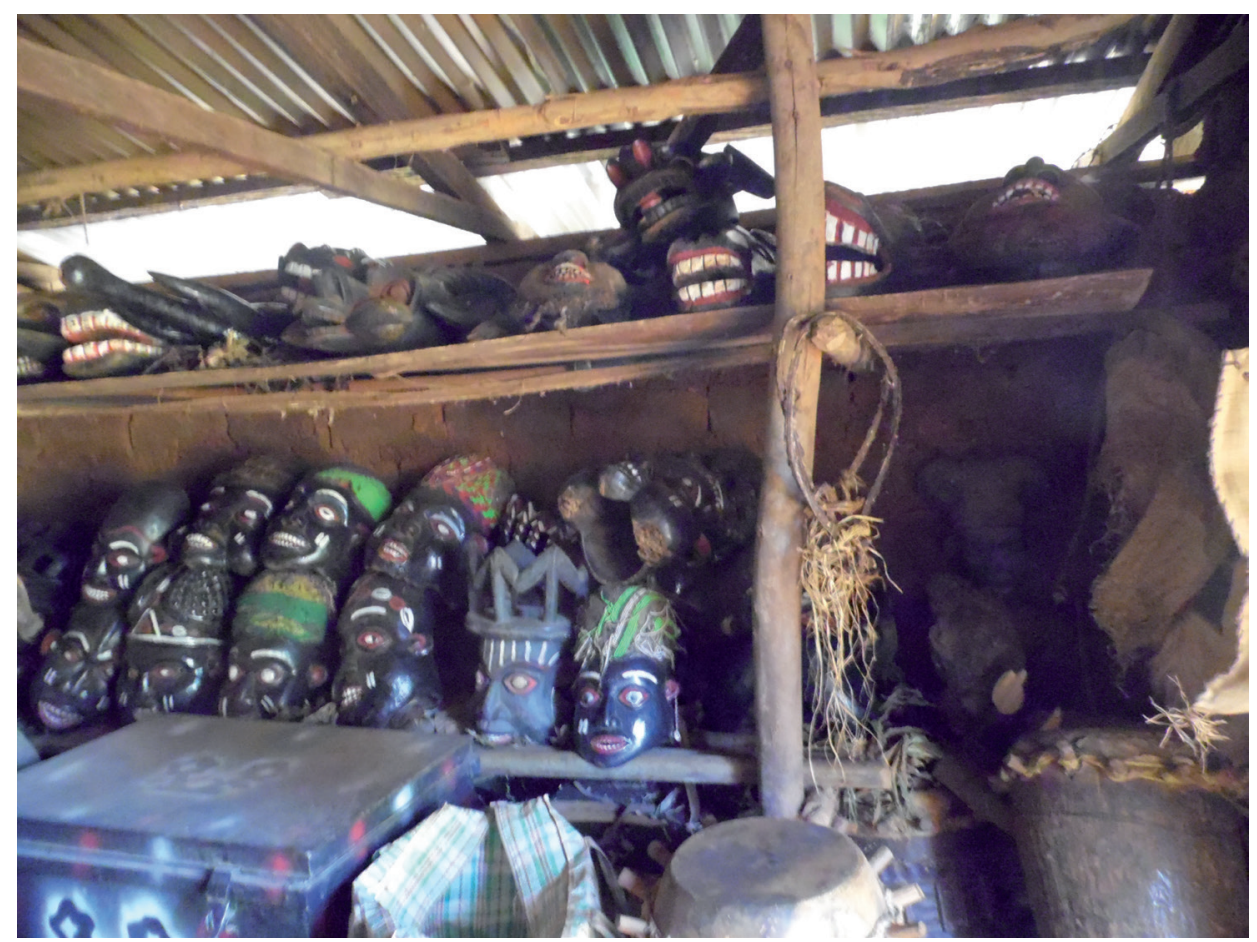

Figure 4. A cross-section of masks and other categories of objects from the Bambui royal treasury, awaiting the completion of the modern museum where they will be housed. Bambui, Cameroon. December 2015

These restrictions were strictly enforced by putting in place disciplinary techniques or what Michel Foucault calls dispositive, which are the various institutional, physical and administrative mechanisms and knowledge structures which enhance and maintain the exercise of power within the social body (Foucault 1979). Put differently, measures aimed at sanctioning defaulters. For example, untitled men and commoners, as well as unclean men and women who dare violate these rules were heavily fined and punished. Moreover, defaulters (if any) were accused of, and associated with "witchcraft-related practices, since it was widely believed that only witches or sorcerers could be bold enough to disobey the authority of traditional elites, or to subvert the dominant social and political order overseen by the Grassfields customary elite system of chieftaincy" (Malaquais 2002: I23-25). In some cases, they were cursed and punished with illnesses such as leprosy. An informant in Kedjom Ketingo, one of the neighbouring villages, told me that the disappearance of leprosy across the western Grassfields is the result of the kingdom losing most of the secret treasures that could cause people to disobey traditional law (by viewing them) and be punished with the illness. In Bambui, the defaulters were not only cursed, 
but some were actually killed by throwing them at Mbohtikobotu, or valley of darkness a deep and dark valley into which defaulters of traditional religious practices were thrown in the past. This practice and punishment did not end with the victims alone; it also extended to and affected their family members. For example, family members of anyone thrown at Mbohtikobotu were not allowed to mourn or perform the religious rites associated with mourning across the Grassfields and the Bambui Kingdom. In fact, this type of death was considered a "silent death" and the entire community was expected to go about their businesses as if nothing had happened. With all these restrictions and sanctions, the royal treasury posed a major challenge to Bambui, and by extension, Grassfields commoners and untitled men as well as youths.

As a result of these restrictions, untitled men, including commoners and youths see the modern museum initiative as an instrument in the counter-hegemonic project. Indeed, untitled men thought it is through having a modern museum in the palace that they could challenge the overwhelming regime of chieftaincy and notability, which, as mentioned earlier, gives status to customary and politico-bureaucratic elites at the expense of social juniors and women. More importantly, this royal treasury resistance enables the newly emerging class of youths, with their education, modern ideas and modern museum to contest, not only the pre-eminent position of the Bambui customary leaders in the royal treasury and other institutions of status and prestige, but also their claims of exercising control over local people through what I would dare call modern museum governmentality. Because the emerging modern museum initiative embodies the desire of Bambui untitled men and women to overturn to their own advantage particular configurations of power and hierarchy that have so far characterized the Bambui traditional society, it is possible to read these developments as an instrument in contemporary and youth association members' efforts to have a say in the accumulation and management of the treasures of the kingdom. However, by pointing out the "obscure" reason behind their interest in the modern museum initiative, I am not suggesting that the interest in the modern museum in the Bambui palace does not also boost the image of youths as people who can shape their own life condition.

Across Bambui, contemporary and youth association members' interest and obsession with the modern museum initiative as a means to access the undemocratic royal treasury tie into the traditional elites mode of lobbying for and accumulating objects and institutions of status and prestige. It also shows the ambition of these contemporary and youth associations across Bambui who have embraced the modern museum initiative to outshine their titleholders and elders in what Arjun Appadurai (I986: 20-2I) calls the "tournament of values". Tournament of values here describes the complex ways in which traditional or cultural elites in the Grassfields and Bambui use the royal treasury and its collections to portray the power and prestige they have over the rest of the population, including youths. In the same vein, youths see the concept of the modern museum as an opportunity to make their voice heard in the wider Grassfields community (cf. Appadurai I986, I996; Cubit 200I; Brunet et al 2014). As a mark of this tendency, most Bambui contemporary and youth associations both in the village and across Cameroon have taken 
it upon themselves to contribute generously towards the BMEP, precisely because it is not under the custody of titled men and elders. The apex of their generosity towards the BMEP project was in 2013 when an astronomical figure of thirteen million francs cfa was raised during the AGM that took place in the palace. Until then, the call for basic contributions towards the maintenance of the royal treasury fell on deaf ears because most contemporary and youth association members associated it with titled men and elders - and claimed it wasn't their responsibility to contribute towards an institution they are restricted from accessing except through initiations. No doubt, by choosing to contribute generously towards the BMEP project, Bambui contemporary and youth associations are implicitly expressing their opposition to both the Bambui traditional mode of social promotion and the management of the royal treasury. Their action also points to the manner in which modern institutions are perceived in comparison to traditional institutions across the kingdom and region.

\section{Conclusion}

The purpose of this paper was to understand the motivations for the recent upsurge of interest in modern museums in the palaces of the Cameroon Grassfields, and Bambui in particular. Accordingly, the paper identified and discussed the transition from the royal treasury to the modern museum, highlighting its significance. It argued that one of the reasons for the interest in modern museums is the inability of the royal treasury to address the challenges of present day society - such as education, which has made youths unwilling to work as retainers in the palace; and the interest in accumulating resources circulating both within and outside the kingdom, region, and country. The other reason relates to the desire of contemporary and youth association members to have a say in the collection and conservation of the palace artefacts, especially the royal treasury that for various reasons is restricted from untitled men, women and commoners. The paper demonstrated that it is not only the restrictions, but also the system of recruiting retainers to serve in the royal treasury that is undemocratic and needs to be changed. Hence, contemporary and youth associations see the modern museum as an embodiment of the democratic institution they seek.

By addressing the question of the motivations for modern museums in Bambui and the Grassfields, the paper has contributed to the scholarship on Cameroon, and in particular, extended Michael Rowlands seminal work on curating postcolonial past in the Grassfields.

That contribution is driven by the unveiling of the modern museum through the youth groups' motivations - using the museum as a democratic lens through which one can view the undemocratic royal treasury. Thus, the modern museum stands as a continuation not only of the politics of obsession with local and foreign resources across the Grassfields, but it also presents itself as the royal treasury in present day modern society. 


\section{Acknowledgement}

This paper is part of my ongoing work on modern museums in the palaces of the western Grassfields, Cameroon. The draft was first presented at the Art and Museums in Africa Conference organized by the Centre of Africa Studies (CAS), Cambridge at the University of Ghana, Legon in September 20I3. It was again presented at the Institute of Art History Colloquium, Freie University, Berlin in January 2014, and at the School of Art and Aesthetics, Jawaharlal Nehru University, New Delhi, India in February 20I4 - as part of the 'Traveling Seminar' of the Art Histories and Aesthetic Practices Programme of the Forum Transregionale Studien, Berlin to India. The paper has greatly benefitted from my rewarding conversations and discussions with participants to the three workshops.

\section{References}

Appadurai, A. (1986). "Introduction." In A. Appadurai (ed) The Social Life of Things: Commodities in Cultural Perspective. Cambridge University Press. pp. I-72.

Appadurai, A. (1996). Modernity at Large: Cultural Dimensions of Globalization. Minneapolis: University of Minnesota Press.

Argenti, N. (1998). "Air Youth: Performance, Violence and the State in Cameroon." Royal Anthropological Institute of Great Britain and Ireland Journal 4: 753-782.

Argenti, N. (200I). "Kesum-Body and the Places of the Gods: The Politics ofChildren's Masking and Second-World Realities in Oku, Cameroon." The Journal of the Royal Anthropological Institute, Vol. 7, No. I. pp. 67-94.

Assombang, R. (1990). "Museums and African Identity: The Museum in Cameroon - A Critique." West African Journal of Archaeology. Vol. 20. pp. I88-ig8.

Bonu, C. (2012). A Short History and Traditions of Bambui: 1700-2012. Reignite.

Brunet, J., Legoux, R. and Najar, S. (2014). "Press Junkets as Tournaments of Value." Unpublished Paper Submitted for the $3^{\text {th }}$ International Marketing Trends Conference. Venice, Italy. January $24^{-25}$ th, 2014 .

Clifford, J. (1988). The Predicament of Culture: Twentieth-Century Ethnography, Literature and Art. Cambridge, MA. Harvard University Press.

Cubit, S. (200I). "Tournaments of Value: Horses, Wilderness, and the Tasmania Central Plateau." Environmental History 6 (3): 395-4II.

Fabian, J. (1983). Time and the Other: How Anthropology Makes its Objects. New York: Columbia University Press.

Foucault, M. (1979). Discipline and Punish: The Birth of the Prison. Translated by Alan Sheridan. New York: Vintage and Random House.

Forni, S. (200I). "Molding Culture: Pottery and Traditions in the Ndop Plain, North West Province, Cameroon." PhD Dissertation. Universita' Degli Studi Di Torino.

Fubah, M. (2014). "The Changing 'Life' of the Buffalo and Cow Horns and New Methods of Adaptation by Carvers and Patrons in the Grassfields, Cameroon." African Studies73 (I): 4I-57.

Fubah, M. (2013) "Do We Need Museums in the Western Grassfields?" African Research and Documentation No. I2I. pp. 35-54.

Geary, C. (I98I). Bamum Thrones and Stools. African Arts I4 (4): 32-43+87-88.

Geschiere, P., Meyer, B. and Pels, P. (2008). "Introduction.” In P. Geschiere, B. Meyer, and P. Pels (eds.) Readings in Modernity in Africa. Bloomington and Indianapolis: Indiana University Press . pp. I-7.

Hobsbawn, E. and Ranger, T. (1983). The Invention of Tradition. Cambridge: Cambridge University Press.

Homberger, L. (ed.) ( 2000). Cameroon: Art and Kings. Rietberg Museum.

Jindra, M. (2005). "Christianity and the Proliferation of Ancestors: changes in hierarchy and mortuary rituals in the Cameroon Grassfields." Africa: Journal of the International African Institute 75 (3): 356-377. 
Kasfir, S. (1999). Contemporary African Art. London: Thames and Hudson.

Knöpfli, Hans. (1997). Crafts and Technologies: Some Traditional Craftsmen of the Grassfields, Cameroon. Ocasional Paper Number 107. London: British Museum.

Malaquais, D. (1999). "Building in the name of God: architecture, resistance, and the Christian faith in the Bamileke Highlands of Western Cameroon." African Studies Review, 42 (I): 49-78.

Malaquais, D. (2002). Architecture, Pouvoir et Dissidence au Cameroun. Paris: Karthala/Presses de l'UCCAC.

Ndjio, B. (2009). "Migration, Architecture, and the Transformation of the Landscape in the Bamileke Grassfields of West Cameroon." Africa Diaspora. pp. 73-100.

Nettleton, A., Charlton, J., and Rankin-Smith, F. (2002). Engaging Modernities: Transformations of the Commonplace. University of the Witwatersrand Art Galleries.

Nkwi, P. (1996). "A conservation dilemma over African royal art in Cameroon." In: P. Schmidt and R. McIntosh (eds.) Plundering Africa's Past. Bloomington: Indiana University Press . pp. 99-Iog.

Notue, J. P. (2000). The Treasure of the Mankon Palace: Cultural Objects from the Royal Palace. Balmayo: Institut de Formation Artistique.

Notue, J. P. and Triaca, B. (2005). Mankon: Arts, Heritage and Culture from the Mankon Kingdom. Catalogue of the Mankon Museum. 5 Continents.

Notue, J. P. and Triaca, B. (2006). Babungo: Arts, Heritage and Culture from the Mankon Kingdom. Catalogue of the Babungo Museum. 5 Continents.

Ranger, T. and Vaughan, O. (eds.) (1983). Legitimacy and the State in Twentieth-Century Africa. Oxford: Macmillan.

Rowlands, M. (1996). "The Consumption of an African Modernity." In M. Arnoldi, M. Geary, and K. Hardin (eds.) African Material Culture. Bloomington: Indiana University Press. pp. I88-213.

Rowlands, M. (2008). "Africa on Display: Curating Postcolonial Pasts in the Cameroon Grassfields." In P. Schmidt (ed.) Postcolonial Archaeologies in Africa. Santa Fe: School for Advance Social Research Press . pp. I49-162.

Séraphin, G. (2000). Vivre à Douala: L'Imaginaire et l'Action dans une ville africaine en crise. Paris: Karthala.

Warnier, J. P. (1993). “The King as a Container in the Grassfields, Cameroon." Paiduma 39: 303-319. 